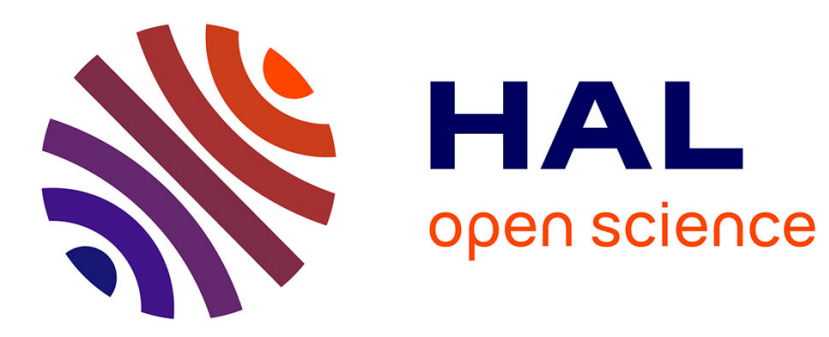

\title{
Assembly of Palladium(II) and Platinum(II) Metallo-Rectangles with a Guanosine-Substituted Terpyridine and Study of Their Interactions with Quadruplex DNA
}

Sushobhan Ghosh, Oscar Mendoza, Leticia Cubo, Frederic Rosu, Valérie Gabelica, Andrew J P White, Ramon Vilar

\section{To cite this version:}

Sushobhan Ghosh, Oscar Mendoza, Leticia Cubo, Frederic Rosu, Valérie Gabelica, et al.. Assembly of Palladium(II) and Platinum(II) Metallo-Rectangles with a Guanosine-Substituted Terpyridine and Study of Their Interactions with Quadruplex DNA. Chemistry - A European Journal, 2014, 20 (16), pp.4772 - 4779. 10.1002/chem.201304905 . inserm-01387138

\section{HAL Id: inserm-01387138 https://www.hal.inserm.fr/inserm-01387138}

Submitted on 25 Oct 2016

HAL is a multi-disciplinary open access archive for the deposit and dissemination of scientific research documents, whether they are published or not. The documents may come from teaching and research institutions in France or abroad, or from public or private research centers.
L'archive ouverte pluridisciplinaire HAL, est destinée au dépôt et à la diffusion de documents scientifiques de niveau recherche, publiés ou non, émanant des établissements d'enseignement et de recherche français ou étrangers, des laboratoires publics ou privés. 


\section{Assembly of palladium(II) and platinum(II) metallo-}

rectangles with a guanosine-substituted terpyridine and

$$
\text { study of their interactions with quadruplex DNA }
$$

Sushobhan Ghosh, ${ }^{1}$ Oscar Mendoza, ${ }^{1}$ Leticia Cubo, ${ }^{1}$ Frederic Rosu, ${ }^{3}$ Valerie Gabelica, ${ }^{4,5}$ Andrew J. P.White ${ }^{1}$ and Ramon Vilar ${ }^{1,2 *}$

${ }^{1}$ Department of Chemistry, Imperial College London, London SW7 2AZ, UK

${ }^{2}$ Institute of Chemical Biology, Imperial College London, London SW7 2AZ, UK

${ }^{3}$ Univ. Bordeaux, IECB, INSERM US001, CNRS UMS 3033, F-33600 Pessac, France

${ }^{4}$ INSERM, U869, IECB, F-33600 Pessac, France

${ }^{5}$ Univ. Bordeaux, ARNA Laboratory, F-33000 Bordeaux, France

*Corresponding author: Prof Ramon Vilar, r.vilar@imperial.ac.uk 
Keywords: Quadruplex DNA; Self-assembly; Palladium; Platinum; Molecular rectangle

\begin{abstract}
.
Two novel [2+2] metallo-assemblies based on a guanosine-substituted terpyridine ligand (1) coordinated to palladium(II) (2a) and platinum(II) (2b) are reported. These supramolecular assemblies have been fully characterized by NMR spectroscopy, ESI mass spectrometry and elemental analyses. The palladium(II) complex (2a) has also been characterized by single crystal X-ray diffraction studies confirming that the system is a [2+2] metallo-rectangle in the solid state. The stabilities of these [2+2] assemblies in solution have been confirmed by DOSY studies as well as by variable temperature ${ }^{1} \mathrm{H}$ NMR spectroscopy. The ability of these di-nuclear complexes to interact with quadruplex and duplex DNA was investigated by Fluorescent Intercalator Displacement (FID) assays, Fluorescence Resonance Energy Transfer (FRET) meting studies, and electrospray mass spectrometry (ESI-MS). These studies have shown that both these assemblies interact selectively with quadruplex DNA (human telomeric DNA and the G-rich promoter region of $c-M y c$ oncogene) over duplex DNA, and are able to induce dimerization of parallel G-quadruplex structures.
\end{abstract}

\title{
Table of Contents Legend
}

The synthesis and DNA binding properties of two novel [2+2] metallo-rectangles are reported. We show by spectroscopic and mass spectrometric techniques that these complexes bind selectively to quadruplex DNA even in the presence of excess duplex DNA. 


\section{Introduction}

Guanine rich sequences of DNA have the ability to fold into four-stranded helical structures named G-quadruplexes. ${ }^{[1]}$ This type of sequences are widespread in the human genome as evidenced by bioinformatic studies. ${ }^{[2-4]}$ Furthermore, there is now compelling evidence showing that such structures exist in vivo in human cells. ${ }^{[5,6]}$ For example, they are found in the telomere which is composed of tandem repeat TTAGGG units. ${ }^{[7]}$ Interestingly, formation of G-quadruplex structures in the telomere has been shown to inhibit the activity of telomerase, an enzyme responsible for telomere maintenance that has been found to be over expressed in $85-90 \%$ of human cancer cells. ${ }^{[8]}$ Since telomerase plays a central role in cancer cell immortalization, it has become an attractive target for the development of anticancer drugs. ${ }^{[7,9]}$ In addition, quadruplex-forming sequences have been found in a large number of gene-promoter regions within the human genome. ${ }^{[4,10]}$ More specifically, the promoter regions of some oncogenes such as $c-M y c$ and c-kit have been found to contain guanine-rich sequences and the formation of quadruplexes has been shown to regulate the expression of the corresponding oncogene. ${ }^{[11-14]}$ Therefore, the design of small molecules which can selectively interact and stabilize G-quadruplex DNA structures has received increasing attention in recent years. ${ }^{[15]}$

Over the past decade a large number of G-quadruplex binders have been developed. ${ }^{[16-18]}$ Most of these have a large planar surface for efficient $\pi-\pi$ stacking on top of the guanine quartet and often feature a positive charge at the center of the molecule and protonable substituents to increase solubility and affinity to DNA. One important issue to consider when developing G-quadruplex binders is that they should have features to enhance their selectivity for quadruplex over duplex DNA. Although several highly selective 
compounds have already been reported, ${ }^{[19-21]}$ they are still few as compared to the many compounds with high affinity for quadruplex but little discrimination over duplex DNA.

We have recently reported a series of metal-terpyridine mono- and bi-metallic complexes and showed them to have high affinity for quadruplex DNA. ${ }^{[22,23]}$ However, particularly in the case of platinum(II) terpyridine complexes, the selectivity for quadruplex over duplex DNA was only modest. This is likely due to the ability of these planar platinum(II)-terpyridine complexes to intercalate in-between base pairs of duplex DNA. We therefore rationalized that a potential strategy to increase selectivity would be to prepare assemblies that, while retaining planar surfaces for efficient $\pi$ - $\pi$ stacking with the external guanine tetrads of quadruplexes, would be too large for intercalation in-between duplex DNA base pairs. Thus the metal-based rectangles $\mathbf{2 a}$ and $\mathbf{2 b}$ (see Figure 1) were developed. A handful of metallo-assemblies have been previously shown to target quadruplexes selectively suggesting that this is a potentially interesting approach. ${ }^{[24-26]}$

Herein we report the synthesis of these two new metallo-assemblies (2a and $\mathbf{2 b})$, their spectroscopic, analytic and structural (for 2a) characterization, as well as binding studies towards quadruplex and duplex DNA. We show that these complexes have high affinity and selectivity for quadruplex over duplex DNA.

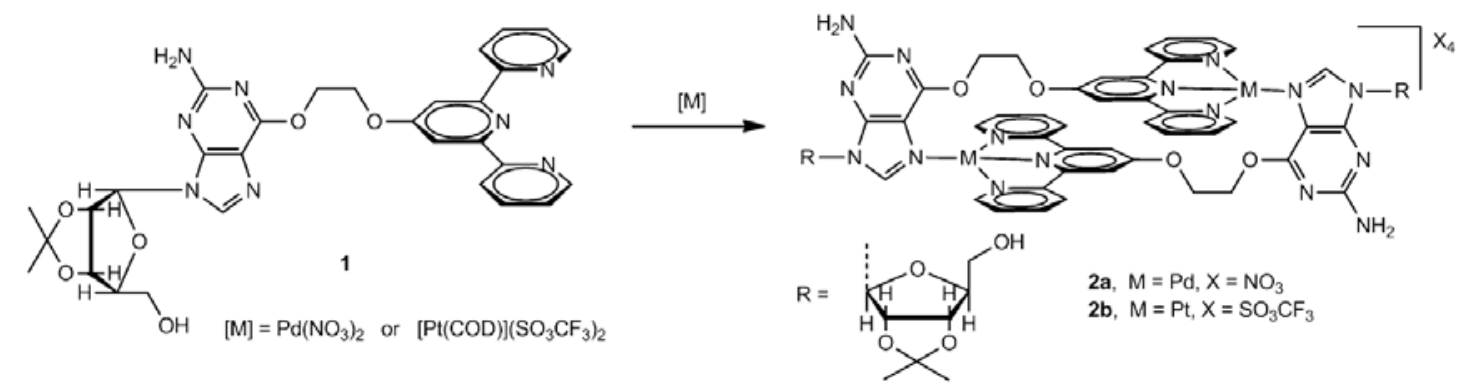

Figure 1. Synthetic scheme for the preparation of supramolecular rectangles $\mathbf{2 a}$ and $\mathbf{2 b}$ from ligand 1 and either $\mathrm{Pd}\left(\mathrm{NO}_{3}\right)_{2}$ or $\left[\mathrm{Pt}(\mathrm{COD})\left(\mathrm{SO}_{3} \mathrm{CF}_{3}\right)_{2}\right]$ respectively. 


\section{Results and Discussion}

Synthesis and Characterization of metallo-rectangles 2a and 2b. Metallo-rectangle 2a was prepared by adding a DMSO solution of ligand $\mathbf{1}^{[27]}$ to a stirred solution of $\operatorname{Pd}\left(\mathrm{NO}_{3}\right)_{2}$ in DMSO in 1:1 ratio. The product was precipitated by addition of acetone to the reaction mixture, filtered and re-dissolved in methanol. Addition of excess ammonium hexafluorophosphate to this solution yielded the $\mathrm{PF}_{6}^{-}$salt of $\mathbf{2 a}$ as a pale yellow precipitate. The platinum(II) analogue $\mathbf{2} \mathbf{b}$ was synthesized by the reaction of $\mathbf{1}$ with $\left[\mathrm{Pt}(\mathrm{COD})\left(\mathrm{SO}_{3} \mathrm{CF}_{3}\right)_{2}\right]$ $(\mathrm{COD}=2,5$ cyclooctadiene) for two days. The resulting orange-yellow suspension was filtered and upon addition of diethyl ether to the filtrate, yielded compound $\mathbf{2} \mathbf{b}$ as a yellow solid.

Pale yellow block shaped crystals of 2a suitable for X-ray crystallographic studies (see supplementary information for details) were grown by slow diffusion of diethyl ether into an acetone solution of the compound, after having been treated with $\mathrm{NH}_{4} \mathrm{PF}_{6}$. The crystal structure of $\mathbf{2 a}$ shows the molecule to have adopted a self-filling rectangular conformation with the central pyridyl ring of each terpyridine unit involved in a back-to-back intramolecular $\pi-\pi$ stacking interaction (interaction $\mathbf{a}$ in Figure 2, Table 1); the centroid $\cdots$ centroid and mean interplanar separations are $c a .4 .06$ and $3.80 \AA$ respectively, with the rings being inclined by $c a .2^{\circ}$. The width of the rectangle is $12.90 \AA$ with an interplanar thickness of around $3.81 \AA$ between the terpyridine faces. Both palladium centers have distorted square planar coordination geometries (Table 1). There are no significant intermolecular $\pi-\pi$ contacts, adjacent supramolecular rectangles instead being linked by a series of $\mathrm{N}-\mathrm{H} \cdots \mathrm{O}, \mathrm{N}-\mathrm{H} \cdots \mathrm{N}$ and $\mathrm{O}-\mathrm{H} \cdots \mathrm{O}$ hydrogen bonds to form a two-dimensional sheet. 
Table 1. Selected bond lengths ( $(\AA)$ and angles $\left(^{\circ}\right)$ for 2 .

$\begin{array}{lcll}\mathrm{Pd}(1)-\mathrm{N}(1) & 1.934(4) & \mathrm{Pd}(2)-\mathrm{N}(51) & 1.932(4) \\ \mathrm{Pd}(1)-\mathrm{N}(8) & 2.038(4) & \mathrm{Pd}(2)-\mathrm{N}(58) & 2.037(4) \\ \mathrm{Pd}(1)-\mathrm{N}(14) & 2.047(4) & \mathrm{Pd}(2)-\mathrm{N}(64) & 2.030(4) \\ \mathrm{Pd}(1)-\mathrm{N}(80) & 2.050(4) & \mathrm{Pd}(2)-\mathrm{N}(30) & 2.032(4) \\ \mathrm{N}(1)-\mathrm{Pd}(1)-\mathrm{N}(8) & 81.17(15) & \mathrm{N}(51)-\mathrm{Pd}(2)-\mathrm{N}(58) & 80.34(15) \\ \mathrm{N}(1)-\mathrm{Pd}(1)-\mathrm{N}(14) & 80.40(15) & \mathrm{N}(51)-\mathrm{Pd}(2)-\mathrm{N}(64) & 80.78(16) \\ \mathrm{N}(1)-\mathrm{Pd}(1)-\mathrm{N}(80) & 178.81(18) & \mathrm{N}(51)-\mathrm{Pd}(2)-\mathrm{N}(30) & 179.02(18) \\ \mathrm{N}(8)-\mathrm{Pd}(1)-\mathrm{N}(14) & 161.57(13) & \mathrm{N}(58)-\mathrm{Pd}(2)-\mathrm{N}(64) & 161.11(13) \\ \mathrm{N}(8)-\mathrm{Pd}(1)-\mathrm{N}(80) & 98.09(14) & \mathrm{N}(58)-\mathrm{Pd}(2)-\mathrm{N}(30) & 99.85(15) \\ \mathrm{N}(14)-\mathrm{Pd}(1)-\mathrm{N}(80) & 100.32(15) & \mathrm{N}(64)-\mathrm{Pd}(2)-\mathrm{N}(30) & 99.01(15)\end{array}$

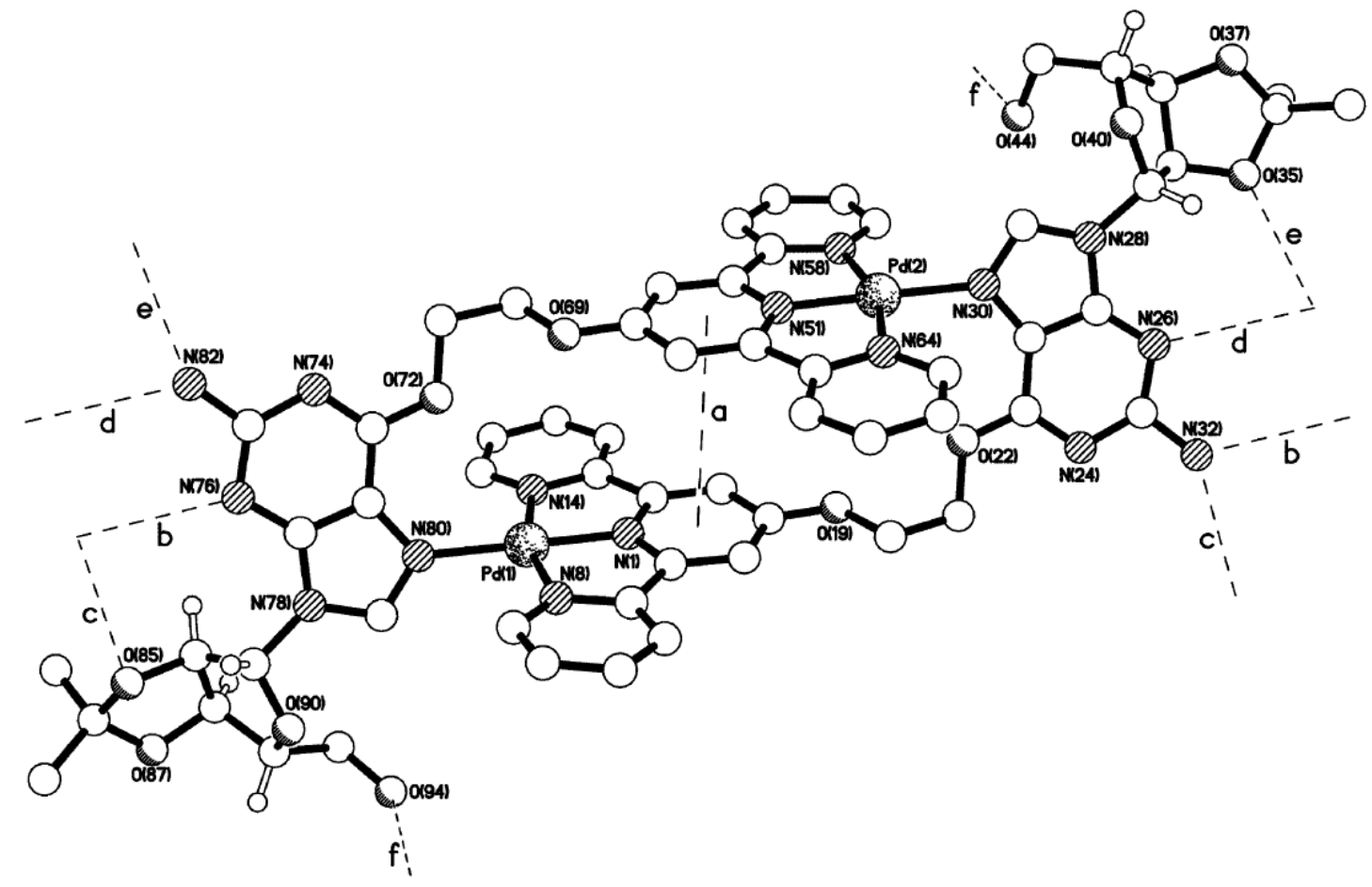

Figure 2. The crystal structure of $\mathbf{2 a}$ showing the intramolecular $\pi-\pi$ contact and the intermolecular hydrogen bonds. The heteroatom $\cdots$ heteroatom distances $(\AA)$ for the hydrogen bonds are b) 3.04 , c) 2.90 , d) 3.11 , e) 2.98 and f) 2.78 . 
The formation of $\mathbf{2} \mathbf{a}$ and $\mathbf{2} \mathbf{b}$ was also confirmed by a range of spectroscopic and analytic techniques. The ${ }^{1} \mathrm{H}$ NMR spectrum of $\mathbf{2 a}$ in acetone (Figure $\mathrm{S} 1$ ), as compared to the free ligand 1, showed significant (up to $1.1 \mathrm{ppm}$ ) downfield shifts for H8 (from guanosine see Figure S1 in the supplementary information for numbering) and for H3 and H4 (from terpyridine). These shifts can be attributed to coordination of ligand $\mathbf{1}$ to palladium as previously shown for analogous systems. ${ }^{[28]}$ In contrast, H5 (from the terpyridine) and H6 (from the alkyl oxy chain) are shifted upfield in $\mathbf{2 a}$ as compared to the free ligand $\mathbf{1}$. This is likely to be due to the intramolecular $\pi-\pi$ stacking interactions in the metallo-assembly (as shown in the solid state structure - see above). The ${ }^{1} \mathrm{H}$ NMR spectrum of the platinum complex $\mathbf{2 b}$ in DMSO-d 6 (supplementary information - Figure S2) is analogous to $\mathbf{2 a}$ which suggests the formation of a metallo-rectangle.

In order to establish whether $\mathbf{2 a}$ and $\mathbf{2 b}$ are indeed [2+2] assemblies in solution, diffusion order NMR experiments (DOSY) were performed in DMSO- $d_{6}$ (see Figure 3 for 2a and Figure S6 for $\mathbf{2 b})$. The diffusion constants were determined to be $0.89 * 10^{-10}$ and $0.91 * 10^{-}$ $10 \mathrm{~m}^{2} \mathrm{sec}^{-1}$ for $\mathbf{2 a}$ and $\mathbf{2 b}$ respectively, and $1.58 * 10^{-10} \mathrm{~m}^{2} \mathrm{sec}^{-1}$ for $\mathbf{1}$. The latter is approximately half the value of that recorded for $\mathbf{2 a}$ and $\mathbf{2 b}$ which is consistent with the presence of the proposed [2+2] metallo-rectangles in solution. The ESI-MS spectra of 2a and 2b showed peaks corresponding to the $[\mathrm{M}]^{+}$and $[\mathrm{M}]^{2+}$ respectively (see supporting information - Figures S3 and S4). 


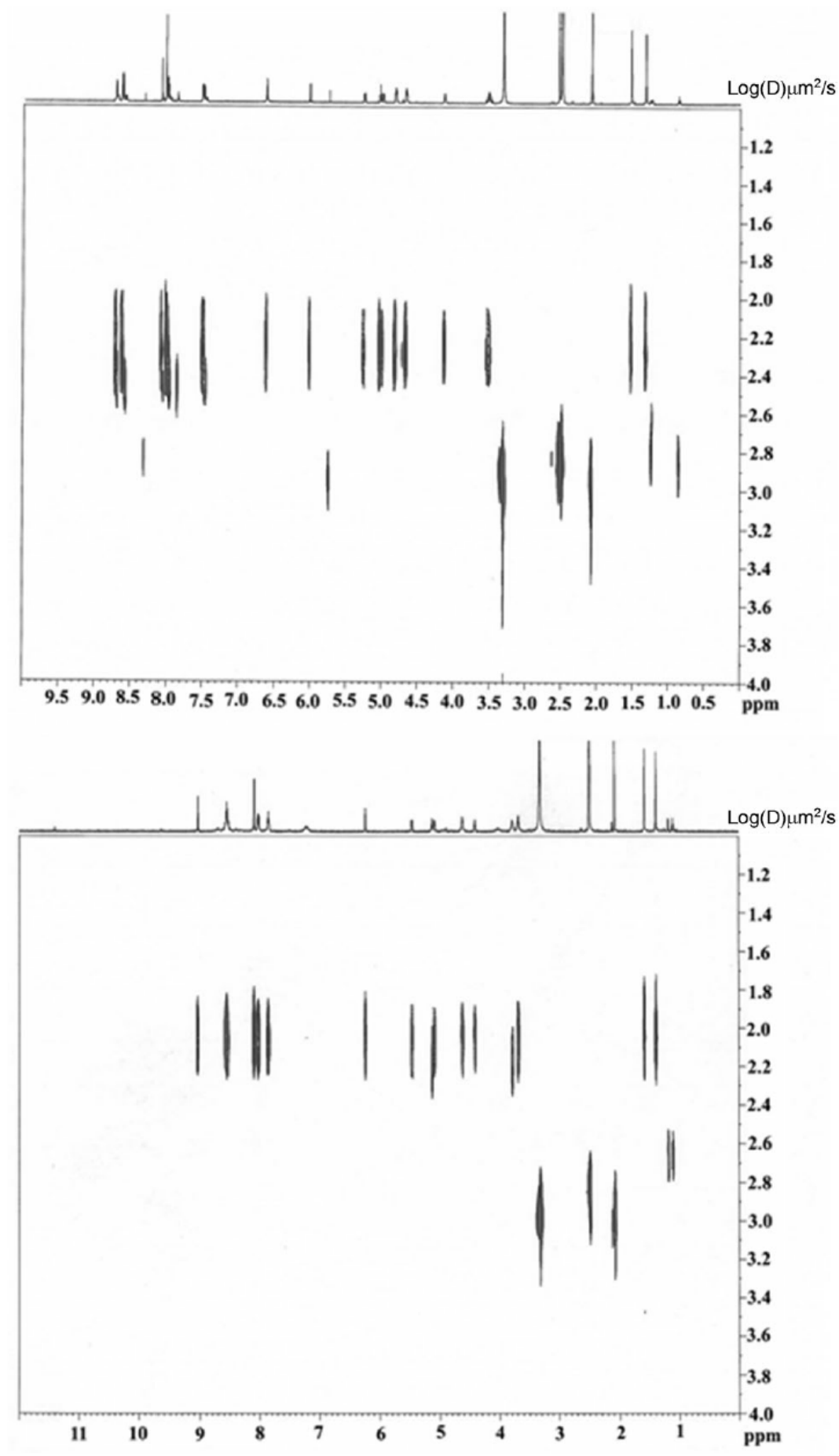

Figure 3. DOSY NMR of ligand 1 (left) and supramolecular rectangle 2a (right) in DMSOd6. The $\mathrm{Y}$-axis represents the log of diffusion constant in $\mu \mathrm{m}^{2} / \mathrm{sec}$. 
Stability of $\mathbf{2 a}$ and $\mathbf{2 b}$ in DMSO/cacodylate buffer solutions. Before studying the affinity of $\mathbf{2 a}$ and $\mathbf{2 b}$ towards DNA, it was of interest to first determine the stability of the metallo-assemblies in solution under the conditions employed for DNA binding assays. Thus, the ${ }^{1} \mathrm{H}$ NMR spectra of the complexes were recorded in a mixture of DMSO- $d_{6}$ and potassium cacodylate buffer $(60 \mathrm{mM})$ in a 1-to-9 ratio (see Figure $\mathrm{S} 5)$. This did not show a significant shift of the guanosine's H8 proton suggesting that it remains coordinated to the corresponding metal centers, strongly suggesting that the assembly is retained in solution. However, it should be noted that significant upfield shifts of aromatic protons H1 and H5 was observed as compared to the ${ }^{1} \mathrm{H}$ NMR spectra in DMSO- $d_{6}$. This can be attributed to intermolecular $\pi-\pi$ stacking interaction between aromatic rings of adjacent rectangles which becomes prominent when the dimer is dissolved in the more polar DMSO-aqueous buffer medium.

Variable temperature ${ }^{1} \mathrm{H}$ NMR spectroscopic studies in DMSO- $d_{6}$ solution were also carried out. These studies showed no significant changes in the spectra (Figures S7 and S8) for neither of the two metallo-assemblies upon increasing the temperature up to $90^{\circ} \mathrm{C}$.

Affinity of $\mathbf{2 a}$ and $\mathbf{2 b}$ for duplex and quadruplex DNA. The binding affinities of the supramolecular rectangles towards the quadruplex forming DNA sequences HTelo and $c-M y c$ (see experimental details for exact sequences) were first investigated by Fluorescent Indicator Displacement (FID) assays. ${ }^{[29]}$ Upon addition of $\mathbf{2 a}$ and $\mathbf{2 b}$ to the corresponding DNA structures previously incubated with thiazole orange (TO), a concomitant decrease in TO's fluorescence intensity was observed (Figure S9 and S10). The degree of displacement of TO by the new complexes (which in turn is a good indication of the ability of a compound to interact with a given DNA structure) was evaluated from the concentration of the compounds required to give a $50 \%$ decrease in dye fluorescence ( $\mathrm{DC}_{50}$ - values shown in Table 2). 
Table 2. $\mathrm{DC}_{50}(\mu \mathrm{M})$ and $\Delta \mathrm{T}_{\mathrm{m}}\left({ }^{\circ} \mathrm{C}\right)$ values for HTelo and c-Myc DNA determined by FID and FRET upon addition of compounds $2 \mathrm{a}-2 \mathrm{~b}$.

$\begin{array}{ccccc} & { }^{\text {Htelo }} \mathrm{DC}_{50}(\mu \mathrm{M}) & { }^{c-m y c} \mathrm{DC}_{50}(\mu \mathrm{M}) & \begin{array}{c}\mathrm{HTelo} \Delta \mathrm{T}_{\mathrm{m}}\left({ }^{\circ} \mathrm{C}\right) \\ (1 \mu \mathrm{M})\end{array} & \begin{array}{c}\mathrm{c}-\mathrm{Myc} \Delta \mathrm{T}_{\mathrm{m}}\left({ }^{\circ} \mathrm{C}\right) \\ (1 \mu \mathrm{M})\end{array} \\ \text { 2a } & 0.42 \pm 0.01 & 0.32 \pm 0.02 & 12.0 \pm 0.7 & 14.9 \pm 0.4 \\ \text { 2b } & 0.99 \pm 0.01 & 0.61 \pm 0.02 & 11.3 \pm 0.4 & 13.8 \pm 0.3\end{array}$

These DC50 values suggest that both $\mathbf{2 a}$ and $\mathbf{2 b}$ have high affinity (especially $\mathbf{2 a}$ ) towards quadruplex HTelo and $c-M y c$ DNA. It is generally accepted that molecules displaying ${ }^{\mathrm{G} 4} \mathrm{DC}_{50}$ values equal to or less than $0.5 \mu \mathrm{M}$ are excellent quadruplex DNA binders. ${ }^{[30]}$

The affinity of $\mathbf{2 a}$ and $\mathbf{2 b}$ towards quadruplex DNA was further investigated using FRET melting experiments using previously established protocols. ${ }^{38,39}$ For the FRET studies, the doubly labeled HTelo F21T [5'-FAM-d(GGGTTAGGGTTAGGGTTAGGG)-TAMRA3' and $c-M y c$ [5'-FAM-d(GGGGAGGGTGGGGAGGGTGGG)-TAMRA-3'] sequences were used and the melting of these sequences investigated at different concentrations of $\mathbf{2 a}$ and $\mathbf{2 b}$ (see Figures 4 and S11). Table 2 summarizes the $\Delta T_{m}$ values which range between $11.3{ }^{\circ} \mathrm{C}$ and $14.9^{\circ} \mathrm{C}$ confirming the good affinity of the complexes towards these two quadruplexes.

In order to investigate the selectivity of the interaction with quadruplex over duplex DNA a competition FRET melting assay was performed following a previously reported procedure. ${ }^{[31]}$ In this experiment the melting of labeled quadruplexes in the presence of $1 \mu \mathrm{M}$ of the corresponding compound (either $\mathbf{2 a}$ or $\mathbf{2 b}$ ) was performed with increasing concentration of calf thymus DNA (ct-DNA) from $0.6 \mu \mathrm{M}$ to $120 \mu \mathrm{M}$ (see Figures $\mathrm{S} 12$ and S13 for melting curves). Figure 5 summarizes the result of the competitive FRET assay. These indicate that both $\mathbf{2 a}$ and $\mathbf{2 b}$ interact selectively with HTelo and $c-M y c$ DNA since there is no significant variation $\left(\leq 2^{\circ} \mathrm{C}\right)$ on the $\Delta T_{m}$ values upon addition of up to $120 \mu \mathrm{M}$ ctDNA. 

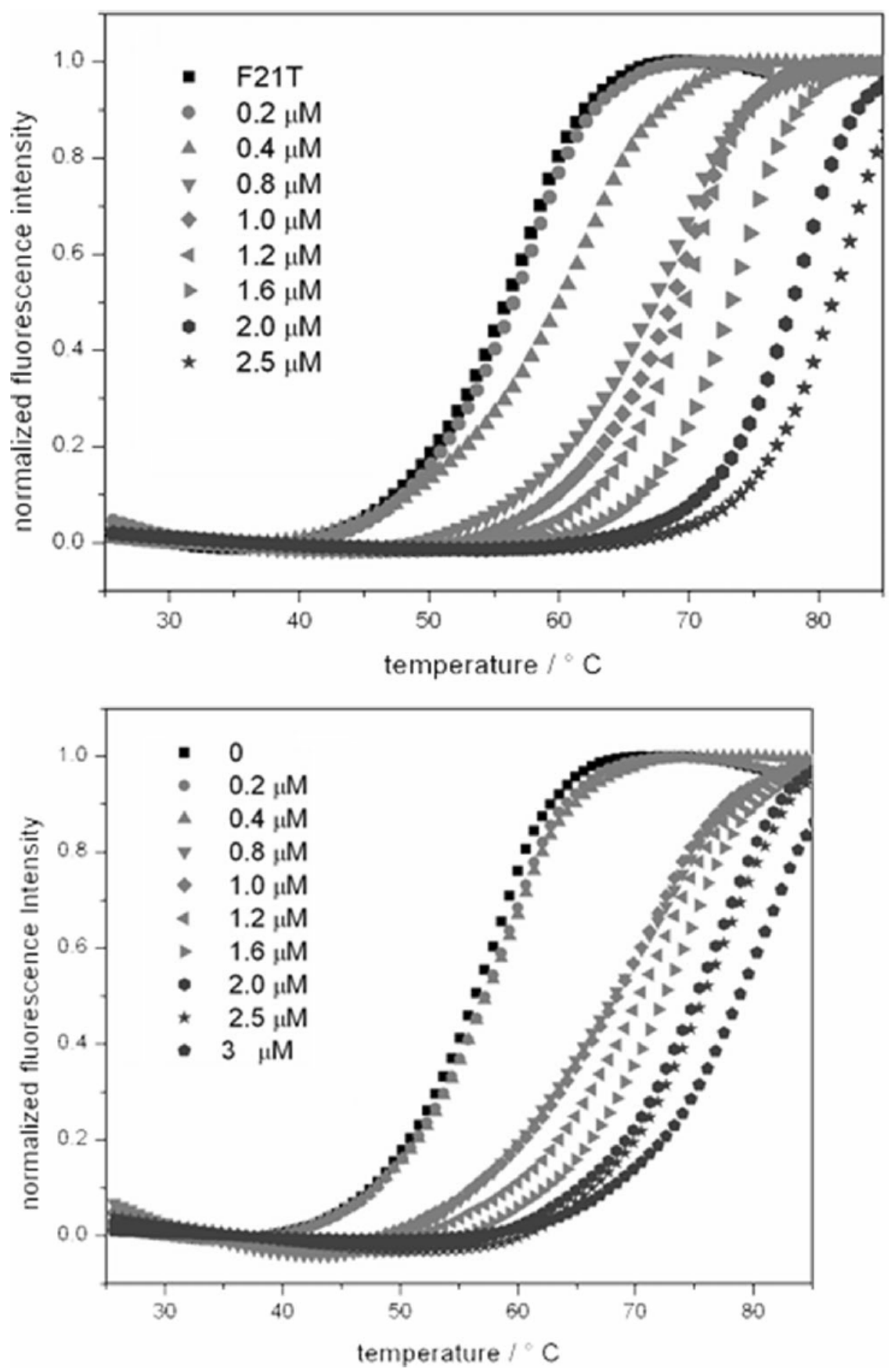

Figure 4. FRET melting assay F21T-Htelo with increasing concentration of 2a from 0-2.5 $\mu \mathrm{M}$ (left) and with increasing concentration of $\mathbf{2 b}$ from $0-3 \mu \mathrm{M}$ (right). 


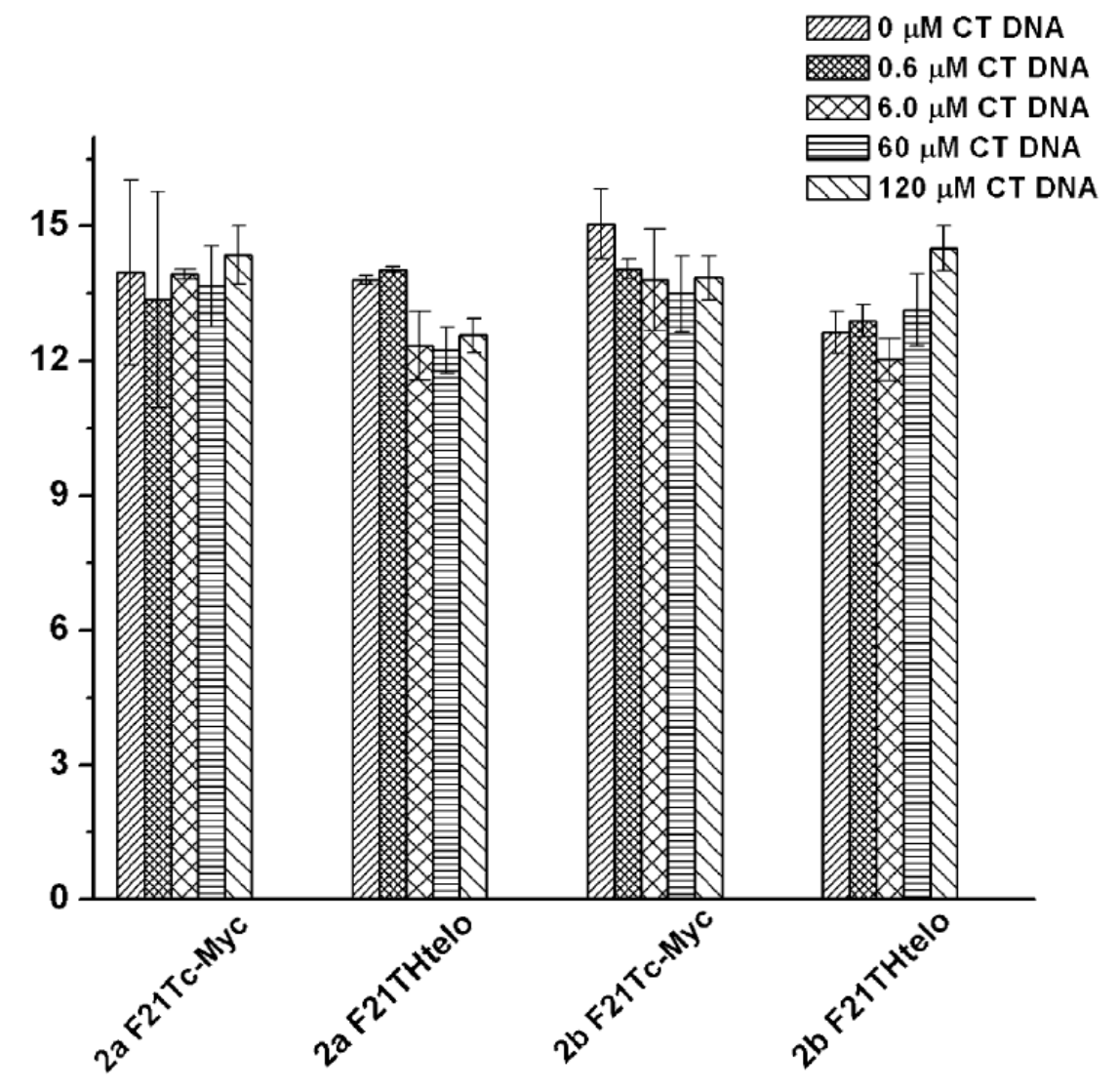

Figure 5. Plot of $\Delta \mathrm{T}_{\mathrm{m}}$ of F21T-Htelo and F21T-cMyc upon addition of $1 \mu \mathrm{M}$ concentration of either $\mathbf{2 a}$ or $\mathbf{2 b}$ and increasing concentration of CT DNA $(0-120 \mu \mathrm{M})$.

ESI-Mass Spectrometry Studies. ESI-MS studies were carried out to investigate further the interaction of the two metallo-rectangles with quadruplex DNA. We were particularly interested in establishing whether the compounds were able to interact as dimers with DNA under the mass spectrometric conditions. For this, we investigated the interaction of both $\mathbf{2 a}$ and $\mathbf{2 b}$ with three duplex DNA sequences of different GC-content, namely d(CGTAAATTTACG)2 (DK33)， d(CGCGAATTCGCG)2 (DK66， the Dickerson-Drew dodecamer) and d(CGCGGGCCCGCG)2 (DK100), three different $c$-Myc quadruplex-forming sequences, namely GGGGAGGGTGGGGAGGGTGGG (21myc), GAGGGTGGGAGGGTGGTAAG (22myc) and TGAGGGTGGGGAGGGTGGGGAAGG (24myc), the parallel tetramolecular G-quadruplex 
$\left(\mathrm{dTG}_{4} \mathrm{~T}\right)_{4}$ and the human telomeric sequence dAGGG(TTAGGG) 3 (22AG) (see Figure S14 for mass spectra of the different sequences in the absence of metal complexes). These studies showed adducts of both dimers (2a and $\mathbf{2 b}$ ) with the different sequences under study. As can be seen in Figure 6 below (and Figure S16 in the supplementary information), the platinum(II) complex $\mathbf{2 b}$ has a greater tendency to bind to DNA (both duplex and quadruplex) as a dimer than the palladium(II) analogue 2a (see Figure S15 in the supporting information) which seems to dissociate more readily under the MS solution conditions, thereby forming DNA adducts as a monometallic complex. Interestingly, $2 \mathbf{b}$ binds preferably with parallel G-quadruplexes (i.e. the $c-M y c$ sequences as well as with the control tetrameric sequence $\left.\left(\mathrm{TG}_{4} \mathrm{~T}\right)_{4}\right)$. We also observed that $\mathbf{2 b}$ favors the dimerization of the parallel quadruplexes (peaks labeled as $[2 \mathrm{Q}+2 \mathrm{~b}]^{\mathrm{z}-}$ in the spectra shown in Figure 6). For the $c-M y c$ sequence derivatives, bimolecular G-quadruplexes are also detected in the absence of ligand, although with a lesser intensity than in the presence of ligand. However, the tetramolecular parallel $d\left(\mathrm{TG}_{4} \mathrm{~T}\right)_{4}$ does form exclusively a tetramolecular species, and no octameric $2 \mathrm{Q}$ species in the absence of ligand. This confirms the ligand-induced assembly properties of $\mathbf{2} \mathbf{b}$ and, to a lesser extent, 2a. Surprisingly, with the 22AG sequence (which is polymorphic and predominantly antiparallel in $\mathrm{NH}_{4}^{+}$), we were not able to detect significant binding with $\mathbf{2 b}$ (only a small peak assigned to the quadruplex $+\mathbf{2} \mathbf{b}$ as a monomer, see peak annotated as $[\mathrm{Q}+\mathrm{b}]^{\mathrm{z}-}$ in Figure $\left.6 \mathrm{c}\right)$. 

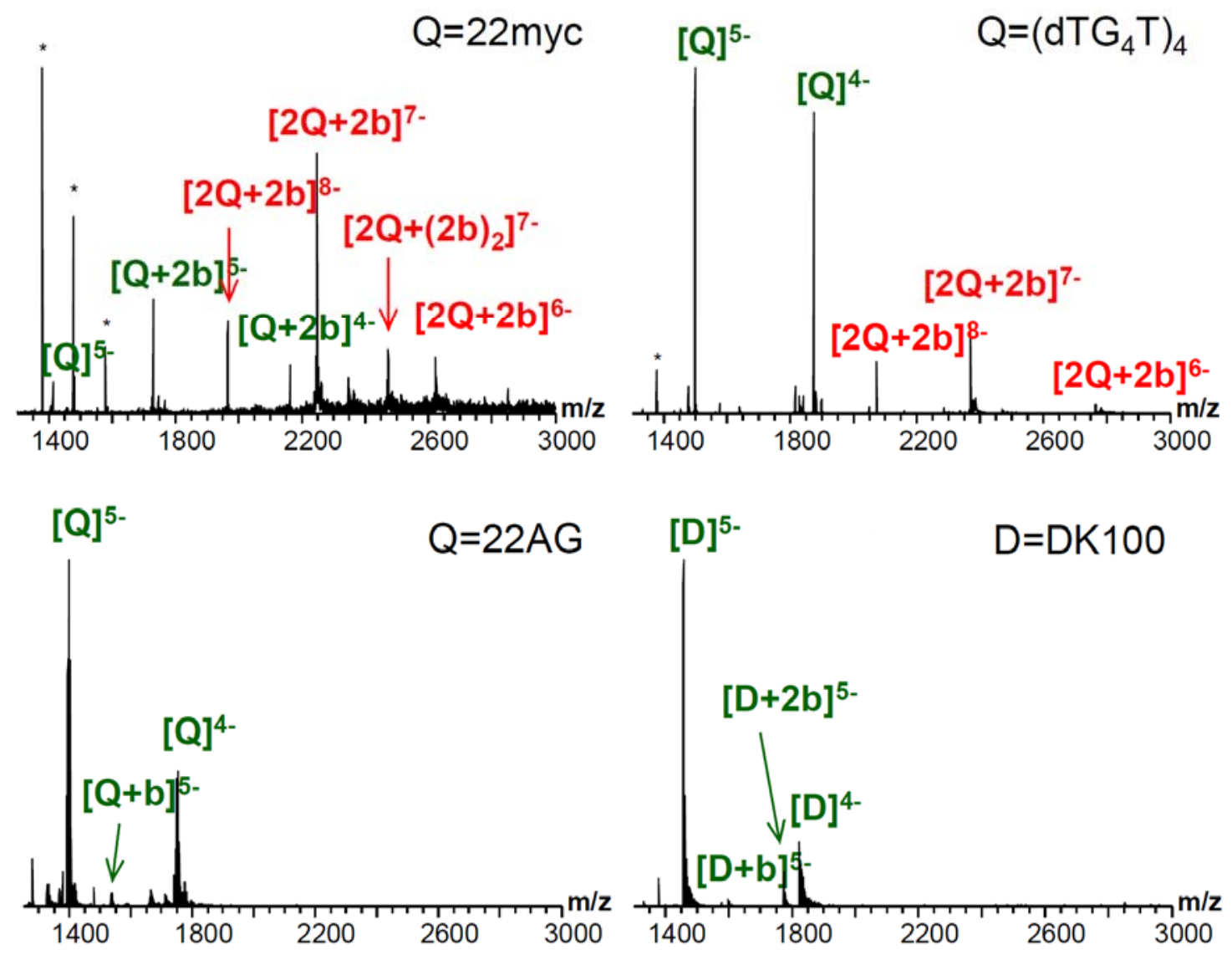

Figure 6. ESI-mass spectra showing the interaction between platinum complex $\mathbf{2 b}$ and: (a) parallel $c-M y c$ quadruplex 22myc; (b) parallel tetrameric $\left(\mathrm{TG}_{4} \mathrm{~T}\right)_{4}$ quadruplex; (c) polymorphic antiparallel 22AG quadruplex and (d) duplex DNA DK100. NOTE: the label "b" corresponds to the $[\operatorname{Pt}(\mathbf{1})]$ fragment while $\mathbf{2 b}$ corresponds to the di-platinum complex. Peaks annotated in green correspond to one DNA subunit, and those in red to ligand-bound dimers of the DNA subunit. Asterisks indicate calibrant peaks.

Docking studies. In order to gain some insight into the binding mode between the metallo-rectangles and quadruplex DNA, docking studies were carried out. The X-ray crystal structure of HTelo quadruplex DNA (structure 1FKF1 from PDB), was docked with the metal complex (using the X-ray crystal structure of 2a) using Autodock. ${ }^{[32]}$ These docking studies showed that the metallo-rectangle can indeed bind to the quadruplex DNA by $\pi-\pi$ stacking (see Figure 7) between one planar face of the rectangle and part of the guanine quartet. 
Interestingly the complex is not located at the center of the quartet and it appears to only interact with one guanine. A phosphate group from the DNA backbone points to the guanosine group of the metal complex ( $3 \AA$ ) suggesting that electrostatic interactions are also playing an important role.
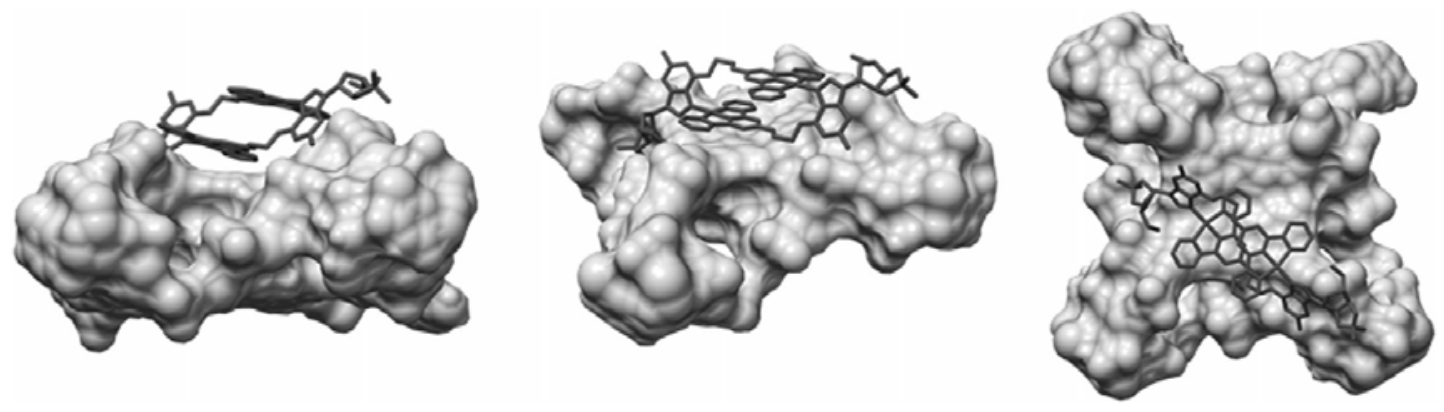

Figure 7. Three different views of the docked model of 2a with HTelo quadruplex DNA (PDB code of the quadruplex structure used for the docking: 1KF1).

\section{CONCLUDING REMARKS}

We have synthesized two new metallo-rectangles (2a-2b) by a self-assembly process between a terpyridyl-based guanosine ligand and the corresponding metal(II) center. From the FID and FRET studies both $\mathbf{2 a}$ and $\mathbf{2 b}$ were found to interact with quadruplex structures from HTelo and $c-M y c$ DNA sequences with higher selectivity compared to the duplex DNA sequences. The binding interactions of $\mathbf{2 a - 2 b}$ with $\mathrm{c}-M y c$ DNA were found to be slightly stronger than the human telomeric DNA sequence. The interaction of these metallorectangles with DNA has been further studied by mass spectrometry. These studies confirm that the compounds interact with quadruplex DNA and, particularly in the case of the platinum(II) complex $\mathbf{2 b}$, the dimetallic structure is retained upon binding. It is also interesting to note that $\mathbf{2} \mathbf{b}$ favors dimerization of G-quadruplex structures, as indicated by the mass spectrometric results. Therefore, the experimental data and computation studies indicate that these di-metallic rectangles interact with G-quadruplex DNA structures via end-stacking. 
Their structure is retained in solution (particularly in the case of platinum) and this is likely to be the reason for the high selectivity for quadruplex vs. duplex DNA they display.

\section{Acknowledgements}

The UK's Engineering and Physical Sciences Research Council (EPSRC) is thanked for financial support including a Fellowship to R.V. (grant number: EP/H005285/1). We are also grateful to EC for a Marie Curie Fellowship (O.M.), to the Royal Society-Newton Fellowship (S.G.) and to the Spanish Government for a fellowship (L.C.M.). V.G. thanks the Inserm (ATIP-Avenir program), the EU (Marie Curie CIG) and the Conseil Régional Aquitaine for funding. Johnson Matthey is thanked for a lone of platinum.

\section{EXPERIMENTAL DETAILS}

Materials, Methods and Instrumentation. ${ }^{1} \mathrm{H}$ NMR, ${ }^{13} \mathrm{C}$ NMR and DOSY NMR spectra were recorded on a BrukerAvance 400 or BrukerAvance 500 spectrometers. Ligand 1 and $\left[\mathrm{Pt}(\mathrm{COD}) \mathrm{Cl}_{2}\right]$ were synthesized according to previously reported procedures. ${ }^{[27,33]}$

Synthesis of Compound 2a. To a stirred solution of $1(30.0 \mathrm{mg}, 0.05 \mathrm{mmol})$ in DMSO a solution of $\mathrm{Pd}\left(\mathrm{NO}_{3}\right)_{2}(12.5 \mathrm{mg}, 0.05 \mathrm{mmol})$ in DMSO was added. The color of the solution changed immediately from deep brown to light yellow. The solution was stirred for 1 $\mathrm{h}$ after which time addition of acetone and diethyl ether (1:4) resulted in the precipitation of a pale yellow solid. The precipitate was redissolved in methanol and an excess ammonium hexafluorophosphate was added to the solution to give a pale yellow precipitate which was formulated as $\left[\mathrm{Pd}_{2}(\mathbf{1})_{2}\right]\left(\mathrm{PF}_{6}\right)_{4}$. Yield: $43 \mathrm{mg}, 87 \%$. Crystals of $\mathbf{2 a}$ were grown by diffusion of diethyl ether into an acetone solution. ${ }^{1} \mathrm{H}$ NMR in acetone- $\mathrm{d}_{6}$ (for numbering of the protons, see supplementary information): $\delta 9.25(\mathrm{~s}, 2 \mathrm{H}$, guanosine-H8); 8.67-8.56 (m, 8H, terpy), 
8.34-8.30 (m, 4H, terpy), $8.08(\mathrm{~d}, J=2.3 \mathrm{~Hz}, 4 \mathrm{H}$, terpy), 7.91-7.87 (m, 4H, terpy), 6.76 (broad s, 4H, $\left.\mathrm{NH}_{2}\right), 6.28(\mathrm{~d}, J=2.4 \mathrm{~Hz}, 2 \mathrm{H}$, guanosine sugar-H1'), 5.45-5.43 (m, 2H, guanosine sugar-H2'), 5.14-5.12 (dd, $J=6.0,2.0 \mathrm{~Hz}, 2 \mathrm{H}$, guanosine sugar-H3'), 4.81-4.79 (t, $\left.J=4.0 \mathrm{~Hz}, 4 \mathrm{H}, \mathrm{CH}_{2}\right), 4.60(\mathrm{t}, J=5.2 \mathrm{~Hz}, 2 \mathrm{H}$, guanosine sugar- $\mathrm{OH}), 4.57-4.54(\mathrm{~m}, 2 \mathrm{H}$, guanosine sugar-4'), $4.30-4.24\left(\mathrm{~m}, 4 \mathrm{H}, \mathrm{CH}_{2}\right), 3.90-3.86(\mathrm{~m}, 4 \mathrm{H}$, guanosine sugar-5'), 1.62 (s, 6H, $\left.\mathrm{CH}_{3}\right), 1.42\left(\mathrm{~s}, 6 \mathrm{H}, \mathrm{CH}_{3}\right) \mathrm{ppm} .{ }^{13} \mathrm{C}$ NMR acetone-d6: $\delta 171.1,162.4,159.4,158.0$, $157.9,154.1,153.7,144.6,142.7,130.6,126.3,114.2,112.3,111.1,93.6,89.5,85.7,82.6$, 70.0, 65.3, 63.2, 27.4, 25.4 ppm. ESI(+)-MS: Calculated $\mathrm{Mw}$ for $\left(\mathrm{C}_{60} \mathrm{H}_{60} \mathrm{~F}_{24} \mathrm{~N}_{16} \mathrm{O}_{12} \mathrm{P}_{4} \mathrm{Pd}_{2}\right)=$ 1989.9 a.m.u. Found $\left[\mathrm{M}-\mathrm{PF}_{6}\right]^{+}=1842.2 ;\left[\mathrm{M}-2 \mathrm{PF}^{6}\right]^{2+}=850.0$ a.m.u. Elemental analysis calculated for $\mathrm{C}_{60} \mathrm{H}_{60} \mathrm{~F}_{24} \mathrm{~N}_{16} \mathrm{O}_{12} \mathrm{P}_{4} \mathrm{Pd}_{2}$ : \%C, 36.21; \%H, 3.09; \%N, 11.26; Found \%C, 35.97; $\% \mathrm{H}, 3.00 ; \% \mathrm{~N}, 11.11$.

Synthesis of Compound $\mathbf{2 b}$. To a stirred suspension of [ $\left.\mathrm{Pt}(\mathrm{COD}) \mathrm{Cl}_{2}\right](18.7 \mathrm{mg}, 0.05$ mmol) in $\mathrm{MeCN}$ ( $5 \mathrm{ml}), \mathrm{Ag}\left(\mathrm{SO}_{3} \mathrm{CF}_{3}\right)(25.6 \mathrm{mg}, 0.1 \mathrm{mmol})$ was added and the resulting mixture was stirred at room temperature for $12 \mathrm{~h}$. After this time the white precipitate formed was filtered and ligand $1(30.0 \mathrm{mg}, 0.05 \mathrm{mmol})$ was added to the clear light yellow filtrate. The resultant mixture was stirred for 2 days at room temperature resulting in an orange yellow suspension. After centrifugation and separation of the solid pellet, a clear yellow solution was obtained and subsequently reduced to one fourth its volume. Diethyl ether was added to this solution to give $\mathbf{2} \mathbf{b}$ as a yellow solid. Yield $40 \mathrm{mg}, 74 \%$. ${ }^{1} \mathrm{H}$ NMR in DMSO-d6 (for numbering of the protons, see supplementary information): $\delta 9.13(\mathrm{~s}, 2 \mathrm{H}$, guanosine-H8), 8.59-8.54 (m, 8H, terpy), 8.23-8.19 (m, 4H, terpy), 8.07 (s, 4H, terpy), 7.91-7.89 (m, 4H, terpy), 7.02 (broad s, 4H, NH 2$), 6.28$ (d, $J=2.3 \mathrm{~Hz}, 2 \mathrm{H}$, guanosine-H1'), 5.53-5.52 (dd, $J=$ 6.0, $2.0 \mathrm{~Hz}, 2 \mathrm{H}$, guanosine-H2'), 5.10-5.09 (dd, $J=8.2,2.8 \mathrm{~Hz}, 2 \mathrm{H}$, guanosine-H3'), 4.9 (broad s, OH), 4.61-4.60 (m, 4H, $\mathrm{CH}_{2}$ ), 4.44-4.41 (m, 2H, guanosine-H4'), 3.89-3.86 (m, 4H, $\left.\mathrm{CH}_{2}\right)$, 3.72-3.69 (m, 4H, guanosine-H5'), $1.61\left(\mathrm{~s}, 6 \mathrm{H}, \mathrm{CH}_{3}\right), 1.42\left(\mathrm{~s}, 6 \mathrm{H}, \mathrm{CH}_{3}\right) \mathrm{ppm} .{ }^{13} \mathrm{C}$ 
NMR DMSO- $d_{6}: \delta 172.1,162.8,160.0,158.6,158.0,154.5,153.8,145.7,142.7,131.1$, $127.0,116.8,114.5,112.1,94.0,89.9,85.8,83.0,70.7,65.3,63.6,27.7,25.7$ ppm. ESI(+)MS: Calculated $\mathrm{M}_{\mathrm{w}}$ for $\left(\mathrm{C}_{64} \mathrm{H}_{60} \mathrm{~F}_{12} \mathrm{~N}_{16} \mathrm{O}_{24} \mathrm{Pt}_{2} \mathrm{~S}_{4}\right)=2183.7$ a.m.u.; $\mathrm{M}^{+}:\left(\mathrm{M}_{\mathrm{w}}-\mathrm{SO}_{3} \mathrm{CF}_{3}\right)=$ 2034.58; $\mathrm{M}^{2+}:\left(\mathrm{M}_{\mathrm{w}}-2 \mathrm{SO}_{3} \mathrm{CF}_{3}\right) / 2=942.75$. Found $\left[\mathrm{M}-\mathrm{SO}_{3} \mathrm{CF}_{3}\right]^{+}: 2035.4$ a.m.u.; $[\mathrm{M}-$ $\left.2 \mathrm{SO}_{3} \mathrm{CF}_{3}\right]^{2+}$ : 942.7 a.m.u. Elemental analysis calculated for $\left[\mathrm{C}_{64} \mathrm{H}_{60} \mathrm{~F}_{12} \mathrm{~N}_{16} \mathrm{O}_{24} \mathrm{Pt}_{2} \mathrm{~S}_{4} \cdot\left(\mathrm{H}_{2} \mathrm{O}\right)_{4}\right]$ : $\% \mathrm{C}, 34.08 ; \% \mathrm{H}, 3.04 ; \% \mathrm{~N}, 9.94$. Found: $\% \mathrm{C}, 33.62 ; \% \mathrm{H}, 2.70 ; \% \mathrm{~N}, 9.76$.

Stock Solution Preparation. The following stock solutions were prepared and used in the FID and FRET DNA binding studies. The corresponding complex (either 2a or $\mathbf{2 b}$ ) was dissolved in DMSO to give a $1 \mathrm{mM}$ stock solution. All solutions were stored at $-20{ }^{\circ} \mathrm{C}$ and defrosted and diluted immediately before use.

Oligonucleotides. Non-labeled oligonucleotides were purchased from Eurogentec (Belgium); labeled oligonucleotides of double HPLC-grade purity were purchased from IBA solutions for life sciences (Germany). For the telomeric G4 DNA, the 21-mer double-labeled oligonucleotide F21T-HTelo, 5'-FAM-dGGG(TTAGGG)3-TAMRA-3' (donor fluorophore FAM, 6-carboxyfluorescein; acceptor fluorophore TAMRA, 6-carboxytetramethylrhodamine) was used for FRET studies. The 22-mer 5'AGGGTTAGGGTtAGGGTTAGGG- 3' was used in FID and UV-vis binding studies. For $c$ Myc DNA, 21-mer-double labeled oligonucleotide F21T-cMyc, 5'-FAMd(GGGGAGGGTGGGGAGGGTGGG)-TAMRA-3' was used for FRET studies. The 21-mer 5'-GGGGAGGGTGGGGAGGGTGGG-3' was used for FID studies. The DNA sodium salt from calf thymus, ct-DNA (Sigma-Aldrich), was used for the FRET competition assay.

Fluorescent Intercalator Displacement (FID) Measurements. The corresponding oligonucleotide was dissolved as a stock $20 \mu \mathrm{M}$ solution in MilliQ water, annealed to $0.5 \mu \mathrm{M}$ concentration in a $60 \mathrm{mM}$ potassium cacodylate buffer $(\mathrm{pH} 7.4)$ at $85{ }^{\circ} \mathrm{C}$ for $10 \mathrm{~min}$ and allowed to cool slowly to room temperature overnight. Thiazole Orange (TO; Sigma-Aldrich) 
was freshly prepared as a $10 \mathrm{mM}$ stock solution in DMSO. Compounds and TO were dissolved from stock solutions (see above) to the final concentration in a $60 \mathrm{mM}$ potassium cacodylate buffer ( $\mathrm{pH}$ 7.4). Measurements were performed at a final $0.25 \mu \mathrm{M}$ concentration of oligo, $0.5 \mu \mathrm{M}$ concentration of $\mathrm{TO}$, and the compound concentration to test. Samples were left to stand for 3 min before measurements. Data were acquired at room temperature over a range of 510-800 $\mathrm{nm}$ with excitation at $501 \mathrm{~nm}$.

FRET Measurements. Two different buffers were used for this assay: (a) a mixture of $10 \mathrm{mM}$ potassium cacodylate and $50 \mathrm{mM}$ lithium cacodylate (pH 7.4); (b) a $60 \mathrm{mM}$ potassium cacodylate buffer ( $\mathrm{pH}$ 7.4). F21T-Htelo labeled oligo (see above) was dissolved as a stock $20 \mu \mathrm{M}$ solution in MilliQ water and then annealed at a $400 \mathrm{nM}$ concentration in a 60 $\mathrm{mM}$ potassium cacodylate buffer $(\mathrm{pH} 7.4)$ at $85{ }^{\circ} \mathrm{C}$ for $10 \mathrm{~min}$ and allowed to cool slowly to room temperature overnight. Compounds were dissolved from stock solutions (see above) to final concentrations in a $60 \mathrm{mM}$ potassium cacodylate buffer ( $\mathrm{pH}$ 7.4). Each well of a 96-well plate contained $200 \mathrm{nM}$ oligo and compound to test. Measurements were performed on a PCR Stratagene Mx3005P (Agilent Technologies) with excitation at 450-495 nm and detection at $515-545 \mathrm{~nm}$. Readings were taken from 25 to $95{ }^{\circ} \mathrm{C}$ at intervals of $0.7{ }^{\circ} \mathrm{C}$, maintaining a constant temperature for $30 \mathrm{~s}$ before each reading. F21T-cMyc labeled oligo was dissolved as a stock $20 \mu \mathrm{M}$ solution in MilliQ water and then annealed at a $400 \mathrm{nM}$ concentration in a mixture of $10 \mathrm{mM}$ potassium cacodylate and $50 \mathrm{mM}$ lithium cacodylate as the buffer ( $\mathrm{pH} 7.4)$.

FRET Competition Studies. F21T-Htelo oligo (see above) was dissolved as a stock 20 $\mu \mathrm{M}$ solution in MilliQ water, then annealed as a $400 \mathrm{nM}$ concentration in $60 \mathrm{mM}$ potassium cacodylate buffer $(\mathrm{pH} 7.4)$ at $85{ }^{\circ} \mathrm{C}$ for $10 \mathrm{~min}$, and allowed to cool slowly to room temperature overnight. A $10 \% \mathrm{w} / \mathrm{v}$ solution of ct-DNA in buffer was stirred gently over 3 days and then centrifuged for $3 \mathrm{~min}(1200 \mathrm{rpm})$ to remove non-soluble oligo. The 
concentration and purity of the supernatant was determined by absorbance reading on a CARY 300 BIOUV-visible spectrophotometer and then diluted to correct concentrations. Compounds were dissolved from stock solutions (see above) to final concentrations in the buffer. Each well of a 96-well plate was prepared with a final $200 \mathrm{nM}$ oligo concentration, 1 $\mu \mathrm{M}$ compound concentration, and the ct-DNA concentration to test. Measurements were performed under the same conditions as the FRET assay (see above). For F21T-cMyc a stock solution of $20 \mu \mathrm{M}$ in MilliQ water was diluted with a mixture of $10 \mathrm{mM}$ potassium cacodylate and $50 \mathrm{mM}$ lithium cacodylate as the buffer ( $\mathrm{pH} 7.4)$.

Computational studies. Docking studies were carried out using Autodock (Version 4.2). ${ }^{[32]}$ The structure of quadruplex DNA used as a model was the crystal structure of human telomeric DNA (PDB:1KF1). This crystal structure shows a parallel intrastranded quadruplex structure with both guanine quartets uncovered and therefore it allows possible interaction with the quartets. Autodock Tools was used to generate the pdbqt files required for both the DNA and the complex. All the polar hydrogens were added and non-polar hydrogens emerged in these files. For the docking modelling, the DNA structure was kept rigid during the docking while the metal complex was allow to have rotatable bonds. DNA was enclosed in the grid box defined by Auto Grid (dimensions $60^{\prime \prime} \times 60^{\prime \prime} \times 60^{\prime \prime} \AA$ ) used for dispersion/repulsion, hydrogen bonding, electrostatics, and desolvation, respectively. Auto Grid performed a pre-calculated atomic affinity grid maps for each atom type in the ligand plus an electrostatics map and a separate desolvation map present in the substrate molecule. Then, during the AutoDock calculation, the energetics of a particular ligand configuration is evaluated using the values from the grids. Ligand docking was carried out with the AutoDock 4.2 Lamarckian Genetic Algorithm (LGA) with an initial population of 150 randomly placed individuals, a maximum number of $25 * 106$ energy evaluations and a probability of performing local search on individual of 0.15 . One hundred independent docking runs were 
performed and the results clustered with a RMSD of $2.0 \mathrm{~A}{ }^{\circ}$. Other parameters were set as default. The estimated free energy for the best binding was computed to be $-7.76 \mathrm{kcal} / \mathrm{mol}$.

Mass Spectrometry. Mass spectrometry experiments were carried out on an Exactive orbitrap mass spectrometer (Thermo, Bremen, Germany) equipped with the HESI electrospray source. The experiments were performed in negative ion mode (capillary voltage $=2.7 \mathrm{kV}$ ) in soft source conditions, which were established by injecting the antiparallel dimeric G-quadruplex d(GGGGTTTTGGGG) and selecting voltages and temperatures that

mainly preserve three ammonium ions in the dimer at charge state $5^{-[34]}$ The capillary temperature was $115^{\circ} \mathrm{C}$, the skimmer voltage was $-10 \mathrm{~V}$, the gate lens inject was $-7.1 \mathrm{~V}$, the MP_1_offset $-7.0 \mathrm{~V}$ and the tube lens offset was $-180 \mathrm{~V}$. The oligonucleotide were prepared by annealing $400 \mu \mathrm{L}$ of $50 \mu \mathrm{M}$ oligonucleotide solution (heating at $80^{\circ} \mathrm{C}$ and then cooling to $4{ }^{\circ} \mathrm{C}$ in $100 \mathrm{mM} \mathrm{NH} 4 \mathrm{OAc}(\mathrm{pH}=7)$ and stored at $4{ }^{\circ} \mathrm{C}$. Equimolar mixture 5-to-5 $\mu \mathrm{M}$ of the metal dimer (2a or $\mathbf{2 b}$ ) with the oligonucleotide were prepared before injection. Spectra shown are raw spectra acquired after reaching steady state ion signal during 3-5 minutes.

\section{References}

1. J. T. Davis, Angew. Chem. Int. Ed., 2004, 43, 668-698.

2. A. K. Todd, S. M. Haider, G. N. Parkinson and S. Neidle, Nucleic Acids Res., 2007, 35, 5799-5808.

3. J. L. Huppert, Biochimie, 2008, 90, 1140-1148.

4. J. L. Huppert and S. Balasubramanian, Nucleic Acids Res., 2007, 35, 406-413.

5. G. Biffi, D. Tannahill, J. McCafferty and S. Balasubramanian, Nat. Chem., 2013, 5, 182-186. 
6. Y. N. E. Lam, D. Beraldi, D. Tannahill and S. Balasubramanian, Nat. Commun., 2013, 4, 2792, $2798 \mathrm{pp}$.

7. S. Neidle, FEBS J., 2010, 277, 1118-1125.

8. A. M. Zahler, J. R. Williamson, T. R. Cech and D. M. Prescott, Nature, 1991, 350, 718720.

9. J. F. Riou, L. Guittat, P. Mailliet, A. Laoui, E. Renou, O. Petitgenet, F. Mégnin-Chanet, C. Hélène and J. L. Mergny, Proc. Nat. Acad. Sci., 2002, 99, 2672-2677.

10. N. Maizels and L. T. Gray, PLoS Genet., 2013, 9, e1003468.

11. A. Siddiqui-Jain, C. L. Grand, D. J. Bearss and L. H. Hurley, Proc. Nat. Acad. Sci., 2002, 99, 11593-11598.

12. A. Rangan, O. Y. Fedoroff and L. H. Hurley, J. Biol. Chem., 2001, 276, 4640-4646.

13. S. Rankin, A. P. Reszka, J. Huppert, M. Zloh, G. N. Parkinson, A. K. Todd, S. Ladame, S. Balasubramanian and S. Neidle, J. Am. Chem. Soc., 2005, 127, 10584-10589.

14. J. Seenisamy, S. Bashyam, V. Gokhale, H. Vankayalapati, D. Sun, A. Siddiqui-Jain, N. Streiner, K. Shin-ya, E. White, W. D. Wilson and L. H. Hurley, J. Am. Chem. Soc., 2005, 127, 2944-2959.

15. G. W. Collie and G. N. Parkinson, Chem. Soc. Rev., 2011, 40, 5867-5892.

16. A. Arola and R. Vilar, Curr. Top. Med. Chem., 2008, 8, 1405-1415.

17. D. Monchaud and M.-P. Teulade-Fichou, Org. Biomol. Chem., 2008, 6, 627-636.

18. S. N. Georgiades, N. H. Abd Karim, K. Suntharalingam and R. Vilar, Angew. Chem. Int. Ed., 2010, 49, 4020-4034.

19. I. M. Dixon, F. Lopez, A. M. Tejera, J.-P. Estève, M. A. Blasco, G. Pratviel and B. Meunier, J. Am. Chem. Soc., 2007, 129, 1502-1503.

20. R. Rodriguez, S. Muller, J. A. Yeoman, C. Trentesaux, J.-F. Riou and S. Balasubramanian, J. Am. Chem. Soc., 2008, 130, 15758-15759. 
21. A. De Cian, E. DeLemos, J.-L. Mergny, M.-P. Teulade-Fichou and D. Monchaud, J. Am. Chem. Soc., 2007, 129, 1856-1857.

22. K. Suntharalingam, A. J. P. White and R. Vilar, Inorg. Chem., 2009, 48, 9427-9435.

23. K. Suntharalingam, A. J. P. White and R. Vilar, Inorg. Chem., 2010, 49, 8371-8380.

24. X.-H. Zheng, Y.-F. Zhong, C.-P. Tan, L.-N. Ji and Z.-W. Mao, Dalton Trans., 2012, $41,11807-11812$.

25. R. Kieltyka, P. Englebienne, J. Fakhoury, C. Autexier, N. Moitessier and H. F. Sleiman, J. Am. Chem. Soc., 2008, 130, 10040-10041.

26. N. P. E. Barry, N. H. Abd Karim, R. Vilar and B. Therrien, Dalton Trans., 2009, 10717-10719.

27. S. Ghosh, G. T. Silber, A. J. P. White, N. Robertson and R. Vilar, Dalton Trans., 2013, 42, 13813-13816.

28. E. Largy, F. Hamon, F. Rosu, V. Gabelica, E. De Pauw, A. Guédin, J.-L. Mergny and M.-P. Teulade-Fichou, Chem. Eur. J., 2011, 17, 13274-13283.

29. D. Monchaud, C. Allain and M.-P. Teulade-Fichou, Bioorg. Med. Chem. Lett., 2006, $16,4842-4845$.

30. D. Monchaud, C. Allain, H. Bertrand, N. Smargiasso, F. Rosu, V. Gabelica, A. De Cian, J. L. Mergny and M. P. Teulade-Fichou, Biochimie, 2008, 90, 1207-1223.

31. C. Romera, O. Bombarde, R. Bonnet, D. Gomez, P. Dumy, P. Calsou, J.-F. Gwan, J.H. Lin, E. Defrancq and G. Pratviel, Biochimie, 2011, 93, 1310-1317.

32. G. M. Morris, D. S. Goodsell, R. S. Halliday, R. Huey, W. E. Hart, R. K. Belew and A. J. Olson, J. Comput. Chem., 1998, 19, 1639-1662.

33. A. Syed, E. D. Stevens and S. G. Cruz, Inorg. Chem., 1984, 23, 3673-3674.

34. F. Balthasart, J. Plavec and V. Gabelica, J. Am. Soc. Mass Spectrom., 2013, 24, 1-8. 